\title{
Development of Interactive Learning Media in Indonesian Language Subjects at VIII Grade of Junior High School
}

\author{
Merry Damanik $^{*}$, Abdul Hasan Saragih ${ }^{1}$, R. Mursid ${ }^{1}$ \\ \{*merrydamanik22@gmail.com $\}$ \\ Department of Educational Tehcnology, Universitas Negeri Medan, Medan, Indonesia ${ }^{1}$
}

\begin{abstract}
The implementation the objectives of Indonesian language subjects in the 2013 curriculum was presented using a text-based approach. In reality, there were still many students who have not been able to construct the text especially the news text. Based on the need's analysis carried out directly on students and teachers at State Junior High School 5 of Tanjung Morawa, that interactive learning media was needed in improving learning outcomes of news text material. The development of interactive media Adobe Flash CS6 was a solution. Interactive Media Adobe Flash CS6 developed using research adopted on a model developed by Lee (2004). The effectiveness of using Adobe Flash CS6 learning media was $82.44 \%$, and without using Adobe Flash CS6 media was $74.37 \%$. Data prove that the use of Adobe Flash interactive learning media material News text was more effective in improving student learning outcomes.
\end{abstract}

Keywords: Interactive media learning, formatting, Indonesian language, news text introduction

\section{Introduction}

Indonesian Language Learning aims that students have the ability to communicate effectively and efficiently in accordance with applicable ethics, both verbally and in writing. Implementing the objectives of Indonesian Language, the Indonesian language learning in the 2013 curriculum was presented using a text-based approach. Text can be in the form of written text or oral text. Text is a complete expression of the human mind in which it has a situation and context.

Writing is used by someone to record or record, convince, report or notify, and influence others. Writing is a whole series of activities of a person to express ideas and convey them through written language to the reader community to be understood [1].

One of the basic competencies of writing skills was that students were able to write news texts. The core competence of news text in the eighth grade of junior high school was that students were able to identify the elements of the news text (boast and motivate) that were heard and read, examined the structure and language of news texts (boast and motivate) that were heard and read by the news, summarized the contents of the news (boast and motivating) which were read and heard, and presented data, information in the form of news verbally and in writing with regard to structure, language, or oral aspects (pronunciation, intonation, expression, kinesics). 
The results of observations conducted by researchers at State Junior High School 5 of Tanjung Morawa, the teacher stated that learning to write news texts for students at the school was still low. The low results were seen from students' learning interests and the results of writing news text training. The teacher also stated that in the practice of writing news texts that have been done, students still lack understanding in the development of elements of $5 \mathrm{~W} 1 \mathrm{H}$, who, what, where, when, why, how to write news texts.

One of the ways that can be done to improve students 'writing skills into enjoyable learning was by active learning by developing teaching materials that were in line with students' characteristics and needs. The development of Adobe Flash CS6 interactive media teaching materials aimed to enable students to learn independently with the guidance of the teacher, or without teacher guidance. This teaching material was a solution in learning to write news texts. Media was one component of communication, according to the Association for Education and Communication Technology [2] .

Interactive multimedia applications used two different software platforms, Adobe Flash CS5 and HTML5 with CSS [3]. This study described applications developed on two different platforms evaluated with one class of 35 students based on four performance criteria to determine students' responses to media use. Experimental results showed that students felt comfortable with the use of Adobe Flash CS5 compared to HTML with CSS.

Developing interactive multimedia based on Adobe Flash Professional CS6 chemical balance in learning can improve learning outcomes and a positive response from students so that students were motivated to learn chemistry [4].

\section{Methodology}

This research was conducted at eighth grade of State Junior High School 5 of Tanjung Morawa in the first semester of 2018/2019 academic year. This study began in July to August 2018 to achieve the purpose of this study, namely the product of interactive media learning of text news in Junior High School (SMP) with Adobe Flash CS6.

Adobe Flash CS6 program was developed to achieve the purpose of this study, namely the product of interactive media learning of text news in State Junior High School (SMPN)with the the overall study used research adopted from the model developed [5] with the following stages:
a. Assessment,
b. Needs Assessment,
c. Front-end analysis
d. Design
e. Development Implementation,
f. Evaluation.
g. Evaluate as shown in the following Figure I [5] 


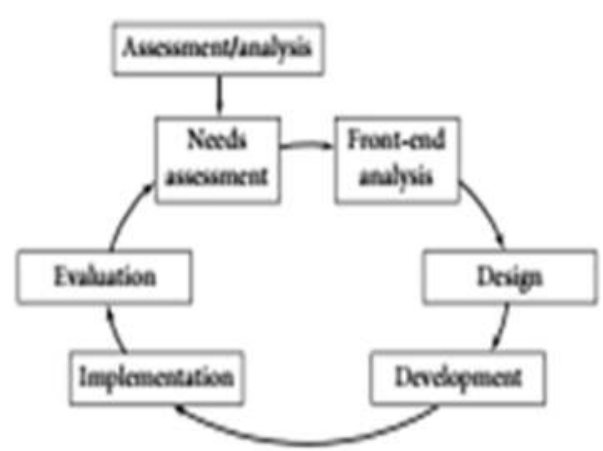

Fig. 1. Depelopmental Process

Table 1. Assessment Criteria

\begin{tabular}{lll}
\hline No. & Categorization & Score Range \\
\hline 1 & Very good & $85 \% \leq \mathrm{x} \leq 100 \%$ \\
2 & Well & $75 \% \leq \mathrm{x}<84 \%$ \\
3 & Medium & $65 \% \leq \mathrm{x}<74 \%$ \\
4 & Not good & $55 \% \leq \mathrm{x}<64 \%$ \\
5 & Very bad & $0 \% \leq \mathrm{x}<55 \%$ \\
\hline
\end{tabular}

Research hypothesis

a. Interactive learning media on news text with Adobe Flash CS6 was suitable to be used as a learning medium in order to achieve the elements of usability, effectiveness and attractiveness of students

b. Interactive learning media on news texts with Adobe Flash CS6 was more effective to be used to improve the learning outcomes of Indonesian language with news text material in eighth grade of SMPN 5 Tanjung Morawa in 2018/2019 academic year.

$\begin{array}{lr}\text { Hypothesis } 1 & : \mathrm{H} 0: \mu \mathrm{A} 1 \leq \mu \mathrm{A} 2 \\ & \mathrm{Ha}: \mu \mathrm{A} 1>\mu \mathrm{A} 2 \\ \text { Hypothesis 2 } & : \mathrm{H} 0: \mu \mathrm{B} 1 \leq \mu \mathrm{B} 2\end{array}$

\section{Result and Discussion}

Table 2. Expert Validation of Materials, Design And Media

\begin{tabular}{llll}
\hline No. & Validator & Average Percentage & Criteria \\
\hline 1 & Expert material & $86.20 \%$ & Very good \\
2 & Learning design experts & $89.20 \%$ & Very good \\
3 & Media expert & $85.79 \%$ & Very good \\
\hline
\end{tabular}

Table 3. Test Result

\begin{tabular}{llll}
\hline No. & Trials & Average Percentage & Criteria \\
\hline 1 & Individual trial & $87.15 \%$ & Very good \\
2 & Small group trial & $89.45 \%$ & Very good \\
\hline
\end{tabular}




\begin{tabular}{llll}
\hline No. & Trials & Average Percentage & Criteria \\
\hline 3 & Field trial & $91.11 \%$ & Very good \\
\hline
\end{tabular}

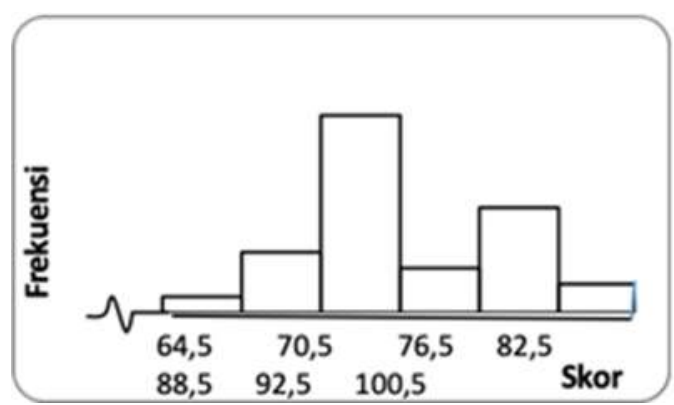

Fig. 2. Histogram of Learning Outcomes of News Texts Learned by Using Interactive Learning Media with Adobe Flash CS6

It was seen that learning using interactive media with Adobe flash CS6 obtained 43.33\% on the average, $26.66 \%$ below the average, and $40.00 \%$ above the average.



Fig. 3. Histogram of News Text Learning Results Learned Without Using Interactive Learning Media with Adobe Flash CS6.

Based on the data obtained, it can be seen that the news text learning outcomes scores on students who learned using Adobe Flash CS6 interactive learning media, obtained the lowest score of 63 and the highest score of 93, the average score was 74.37, standard deviation (Sd) 7, 54, median (Me) 73.00, and mode (Mo) 73.00.

Effectiveness of Indonesian language learning media with Adobe Flash CS6. obtained as follows:

$$
X=X 100 \%=82.44 \%
$$

The effectiveness value of Indonesian language learning media without Adobe Flash CS6 is obtained as follows

$$
X=X 100 \%=74.37 \%
$$




\section{Conclusion}

Based on the results of the research, development and discussion previously stated, it can be concluded:

a. Products in the form of Indonesian language learning interactive media with Adobe Flash CS6 of news text material at the eighth grade of SMPN 5 of Tanjung Morawa in 2018/2019 academic year had the results deserved to be the final product that can be disseminated and implemented to the users. This was clarified by several stages of trials, both trials from material experts, trial of expert learning design, trial of media / graphic design experts, individual trials, group trials and average field trials of all categories are very good.

b. Indonesian language learning media using Adobe Flash CS6 interactive media of news text material was higher than the Indonesian language learning outcomes without using Adobe Flash CS6 interactive media of news text material at the eighth grade of SMPN 5 of Tanjung Morawa in 2018/2019 academic year. These results indicated that the developed interactive multimedia can motivate students to explore the material [6]

\section{References}

[1] G. T.L, Administrasi Perkantoran Modern. Jogjakarta: Liberty, 2002.

[2] AECT, AECT, Defenisi Teknologi Pendidikan satuan Tugas Defenisi dan Terminologi AECT: Seri Pustaka teknologi pendidikan. Jakarta: PT. Raja Grafindo Persada, 1986.

[3] P. S. and S. H. Begum, "Comparative Study of Developing Interactive Multimedia Applications using Adobe Flash and HTML/CSS.," Int. J. Adv. Reseach Comput. Sci. Electron. Engeneering ISSN 2277-9043 Vol 7, No 5., 2018.

[4] Y. R. Saselah and R. Qadar, "Interactive Multimedia Development Based on Adobe Flash CS6 Profesional on Learning of Chemical Equilibrium," JKPK (Jurnal Kim. dan Pendidik. Kim., vol. 2, no. 2, pp. 80-89, 2017.

[5] W. W. Lee and D. L. Owens, Multimedia-based instructional design: computer-based training, web-based training, distance broadcast training, performance-based solutions. John Wiley \& Sons, 2004.

[6] and A. H. S. D. Kurniawan, "Pengembangan Bahan Pembelajaran Interaktif Pada Mata Pelajaran PPKN.," Vol.3.No.1,p-ISSN:2355-4983;e-ISSN;2407-748.201. 